\title{
O homem nas teias da comunicação midiática: uma análise de $O$ Show de Truman'
}

Vander Casaqui

Professor do Programa de Mestrado em Comunicação e Práticas de Consumo da ESPM-SP. Professor da Graduação em Marketing da EACH-USP.

E-mail: vcasaqui@espm.br

A narrativa cinematográfica oferece à análise um imaginário rico em torno das questões que compõem nosso cotidiano. Como produção cultural, que reflete e refrata o espírito de sua época, o cinema traz à luz a representação de temas desenvolvidos em teses. Este artigo propõe-se a refletir, a partir do filme $O$ Show de Truman ${ }^{2}$, sobre pontos relativos à comunicação e à relação do homem com o mundo, mediado pela linguagem. A teoria semiótica de Mikhail Bakhtin serve de base para este estudo.

A relação entre o homem contemporâneo e a mídia se desenvolve claramente no filme estrelado por Jim Carrey. Truman Burbank é um cidadão comum, vendedor de seguros, que vive em Seahaven, uma pequena e pacata cidade. Seu cotidiano é marcado pela rotina: rituais diários, como cumprimentar os vizinhos na saída para o trabalho, repetem-se constantemente. Poderíamos dizer que, em essência, sua vida tem um sentido particular.

As primeiras imagens apresentam o criador do programa falando sobre seu personagem e sobre sua forma genuína de ser, que cativam o espectador, cansado de atores com emoções falsas. Em seguida, mostram Truman em sua prática diária de, ao acordar, dialogar com o espelho do banheiro. Sua imagem é intercalada com depoimentos de pessoas que terão papéis fundamentais no desenvolvimento da trama, como sua esposa, Meryl, e seu melhor amigo, Marlon, como se estivessem sendo entrevistados: sua esposa diz que,

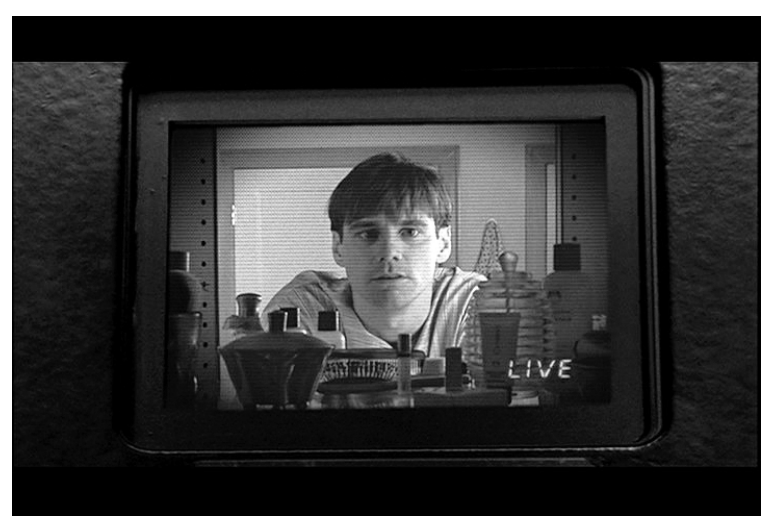

Truman: o homem no espelho, refletido e refratado pela mídia.
1. Agradeço ao mestrando Igor da Costa Bento, do Programa de Mestrado da ESPM-SP, pela colaboração na estruturação deste artigo.

2. O SHOW de Truman (The Truman Show). Direção: Peter Weir. Intérpretes: Jim Carrey; Laura Linney; Ed Harris e outros. Roteiro: Andrew Niccol. Los Angeles: Paramount Pictures, 1998. 1 DVD (103 min.). 
3. Observação de Gustavo Katz, aluno da graduação em Marketing da EACH-USP, no contexto da disciplina Fundamentos da Comunicação.

4. CERTEAU, Michel de. A invenção do cotidiano: 1 . Artes de fazer. Petrópolis: Vozes, 1994. p. 288.

5. BAKHTIN, Mikhail. Marxismo e filosofia da linguagem. São Paulo: Hucitec, 1997. para ela, vida pública e vida privada são indistintas. Seu amigo fala que tudo é verdadeiro, um real controlado.

No decorrer do filme, vemos os paradoxos constituintes da relação de Truman com o meio em que está inserido. Sem saber, o personagem principal, então próximo de completar 30 anos, tem sua vida transmitida ao vivo para milhões de telespectadores: sua existência, aparentemente privada, é um programa televisivo, que acompanha sua trajetória desde que nasceu. Uma atração que combina elementos de realidade com os puramente ficcionais; Truman é um personagem verdadeiro, como seu próprio nome insinua, pela sonoridade: True $\mathrm{Man}^{3}$. Ao seu redor, tudo é expressamente ficcional: sua esposa, seu melhor amigo, as pessoas com quem trabalha, todos são atores ou figurantes. A cidade de Seahaven revela-se, então, uma cidade cenográfica; em certo momento, uma tomada em plano geral mostra o estúdio instalado em meio a um mundo exterior que o comporta. Esse mundo exterior, entendido como um continuum, como representação da realidade, visto somente através de Seahaven, chega a nós a partir dos meios de comunicação; trata-se de um mundo editado, recortado em função da ideologia de um sujeito que se insere no processo comunicativo como um eu, como alguém que produz linguagem e organiza seus componentes em função de um interlocutor. Conforme diz Certeau, "hoje, a ficção pretende presentificar o real, falar em nome dos fatos e, portanto, fazer assumir como referencial a semelhança que produz" ${ }^{\prime 4}$ Certeau refere-se à forma como nossa sociedade tem a capacidade de fabricar o real a partir das aparências, de se sustentar na crença pelo que é visível. O visível que é consumido como real, quando apagados os traços que remetem a seu caráter mediado.

A relação entre Truman e o criador/produtor/diretor do programa, cujo nome é Christof, caracteriza-se, no desenrolar do filme, por situações de comunicação entre eles, como alegoria das estratégias retóricas do último, em função das tentativas de envolver o protagonista em seus objetivos, com as tensões estabelecidas nesse processo interacional, representado pelos encontros e desencontros narrados no filme. O sujeito que organiza a linguagem, no caso o produtor, dá-lhe ordem e um fechamento coerente, na formatação de um discurso que se pretende hegemônico, autoritário, por não revelar sua natureza dialógica $^{5}$. No processo interacional, Truman vai revelar os meandros desse discurso concebido por Christof - torna-se significativo que o criador tenha um nome que, na cultura cristã, se refere ao Filho de Deus, ao representante enviado ao mundo dos homens para expressar a palavra divina: Christ of, o mentor de Seahaven, senhor do discurso que concebe um recorte da realidade, de acordo com sua ideologia, com seus objetivos e com seus valores. Christof fala, por seus personagens, sobre esse mundo no qual Truman deve crer, deve fazer parte sem se constituir como sujeito de sua existência, mas como objeto da mídia.

Truman é um sujeito, em essência, insatisfeito. Seu casamento não vai bem e seus hábitos automatizados tentam, de alguma maneira, sublimar sua 
incompletude, que é derivada de dois sentimentos distintos, porém complementares: a inquietude do personagem em torno do desconhecimento dos mecanismos que revestem sua realidade, com suspeitas alimentadas por situações estranhas, como a queda de um holofote do estúdio na frente de sua casa, no início do filme; e a ausência causada por um amor do passado que não se realizou plenamente, e que ainda o atormenta. Para refletirmos sobre esses dois sentimentos, é preciso recuperar a história passada do personagem. Truman, quando criança, foi desligado do contato com seu pai. Desde jovem, acompanha, com estranhamento, manifestações de pessoas ao seu redor sugerindo que ele vive uma falsa realidade, que está sendo manipulado, que é observado continuamente. Seu pai, encontrando-o na rua, já adulto, tenta lhe revelar a verdade, quando é retirado do programa, de maneira truculenta, pelos seguranças que cuidam da harmonia dos elementos que compõem a realidade em torno de Truman. Essas tentativas de revelar a verdade fizeram dele um ser inquieto em relação à sua existência e ao mundo a sua volta. Se, aparentemente, poderia ser considerado um sujeito assujeitado, alienado pela realidade que o circunda, pelas inúmeras câmeras que acompanham todos os seus passos, que registram cada movimento seu - como na câmera estrategicamente colocada no interior do aparelho de som de seu automóvel -, a desconfiança de que há algo que organiza esse mundo e tenta apagar suas marcas faz de Truman um interlocutor mais atento, um receptor ativo daquilo que o envolve cotidianamente. Para Heller, "a vida cotidiana é a vida do homem inteiro" ${ }^{\text {; }}$; ou seja, o homem vive a cotidianidade com todos seus sentidos, sem, no entanto, ter a plena intensificação dos mesmos, em um paradoxo constituinte que mescla individualidade/autonomia e repetição/incorporação do ritmo coletivo da vida social. Entre escolhas e obrigações, ele se integra aos movimentos do mundo e à sua maneira de percebê-lo individualmente.

A incompletude amorosa de Truman reforça essa maneira atenta com que o personagem procura ler sua realidade. Ela é motivada por uma marca do passado que o transforma e que sustenta muito de sua postura, inclusive na relação vazia que mantém com sua esposa: ainda jovem, conhece uma garota pela qual se apaixona, e que é retirada de sua vida - entenda-se, afastada do programa - por tentar contar-lhe a verdade sobre sua existência televisionada. Sylvia, ao também ser cooptada pelos seguranças do programa, fala a Truman que a encontre nas Ilhas Fiji. As ilhas, país localizado no Pacífico Sul, paraíso turístico distante geograficamente, configura-se na materialidade de uma promessa de felicidade, da esperança de um novo encontro com a mulher de seus sonhos. Pensado a partir da ótica da sociedade de consumo, Fiji surge como objeto de desejo que nunca se realiza; como procura de um sujeito que, em torno das mercadorias, nunca alcança seus objetivos intangíveis - Fiji incorpora o significado da relação afetiva desejada por Truman, mas não se realiza em si: "A aparência que seduz é como um espelho no qual o desejo

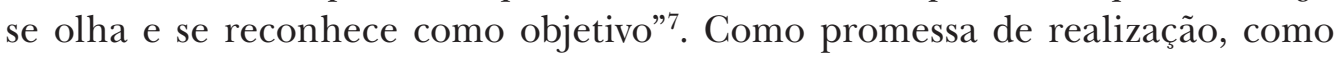

6. HELLER, Agnes. O cotidiano e a história. Rio de Janeiro: Paz e Terra, 1989. p. 17.

7. HAUG, Wolfgang Fritz. A crítica da estética da mercadoria. In: MARCONDES FILHO, Ciro. A linguagem da sedução. São Paulo: Perspectiva, 1988. p. 184 
meta que se insinua como forma de concretização de seus desejos, Fiji se caracteriza, simultaneamente, como possibilidade e como abstração inatingível, alimentando o imaginário do personagem e sua busca.

O consumo em $O$ Show de Truman aponta para o descompasso entre a percepção do desejo do protagonista, representado pelas inúmeras tentativas

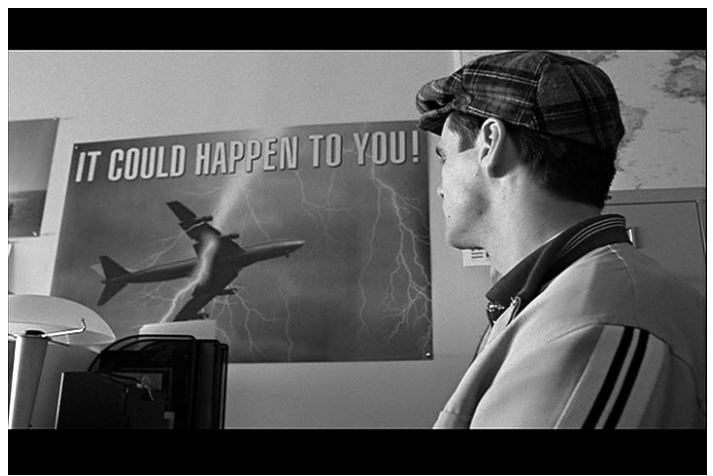

Truman, na agência de viagens, tentando viajar para Fiji: descompassos entre o consumo desejado e o consumo ofertado. de viajar para Fiji, a fim de se conciliar com seus sonhos, e o desestímulo a essa busca, nas mensagens direcionadas por Christof, disseminadas pelos vários discursos que são concebidos em seu mundo: tanto a mídia quanto as pessoas da convivência de Truman tentam demovê-lo da idéia. Uma matéria de capa do jornal local, mostrada por um colega de trabalho, fala sobre Seahaven: o melhor lugar do planeta. Sobre esse ponto, é hilário o momento em que se vê um cartaz, na agência de viagens onde Truman tenta adquirir uma passagem para Fiji, com a imagem de um avião sendo atingido por um raio, e os seguintes dizeres: "Isso poderia acontecer com você".

Simultaneamente à condição de sujeito incapaz de realizar seus desejos a partir do consumo ambicionado, Truman serve de garoto-propaganda involuntário de uma série de produtos organizados no Catálogo Truman, em que tudo aquilo que o personagem consome é oferecido aos telespectadores do programa, com clara expressão da estratégia mercadológica de product placement, ou seja, a inserção de produtos no contexto de atrações midiáticas, de espetáculos que não têm como objetivo revelado o indicativo do consumo de mercadorias, mas que dissemina essa intencionalidade a partir da produção de entretenimento. Vemos isso, de forma rotineira, por exemplo, nas telenovelas, no que é vulgarmente chamado de merchandising; porém, no caso do filme, Truman não tem consciência de que seus atos de consumo são difundidos em larga escala, para estimular o desejo daqueles que acompanham sua vida transmitida via satélite, e que também são constantemente atingidos pelos anúncios protagonizados pelos atores do programa, como a esposa de Truman: são recorrentes as rupturas na comunicação entre o casal, quando a mulher, ao segurar um produto, fala de suas qualidades e o expõe, olhando diretamente para a câmera. Em determinado momento, Truman percebe essa atitude da esposa, questionando-a fortemente: "Com quem você está falando?". Dessa maneira, temos a comunicação representada em ao menos três níveis: figurativizada pelos diálogos entre os personagens do filme, em um simulacro da vida cotidiana; a dimensão da comunicação midiática direcionada aos telespectadores do programa, na concepção espetacular das propostas de consumo; e no filme em si, como produto cultural que dialoga com as questões de seu 
tempo, objetivando despertar o interesse do público para que seja consumido em larga escala.

Na seqüência final do filme, temos a iniciativa de Truman de partir para as ilhas Fiji, a qualquer custo, já tendo percebido que suas tentativas anteriores foram sabotadas - mesmo ainda sem ter consciência plena do contexto onde se insere. Truman, em um pequeno barco, tenta vencer o mar que circunda o lugar onde vive e que o afasta do mundo exterior. O mesmo mar que levou seu pai quando era criança, quando caiu do barco onde os dois pescavam. Vencendo todos os obstáculos naturais, as ondas e ventos provocados para contê-lo, Truman chega ao extremo do estúdio montado para comportar

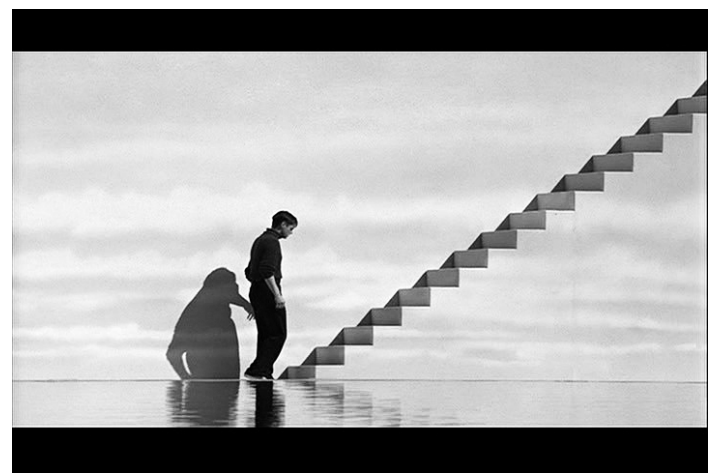

A revelação do mundo editado de Truman: a escada leva à porta de saída da prisão midiática do personagem. sua vida mediada, à parede do cenário que representa o céu - em uma cena que remete à arte de René Magritte, pintor belga (1898-1967).

Truman encontra a escada que o leva à porta de saída do estúdio. Ao abrila, enfim, criador e criatura encontram-se, mediados pelos aparatos técnicos. A voz de Christof ecoa pelo céu, reforçando o tom divino de sua presença, como se estivesse para além das nuvens: "Lá fora a realidade é igual; aqui não há temor". Ele tenta, dessa forma, convencer Truman a permanecer integralmente imerso na mídia, como um telespectador que faz de sua existência o acompanhamento da ficção televisiva, sem perceber que há uma vida a ser vivida, a sua luta cotidiana, a sua forma própria de reorganizar as coisas do mundo e constituir sua identidade, sua história particular, sua vida social e sua ação política. Faz a defesa da hiper-realidade, dos simulacros constituintes da recitação de nossa sociedade ${ }^{8}$. Elementos como o céu cenográfico, a sincronização perfeita do trânsito em torno de Truman e a chuva que somente o atinge deixam tudo ao redor à parte dessa manifestação simulada da natureza. Relações vazias, ambiente asséptico, o ritmo da vida controlado, editado. Truman quer mais. A porta aberta do estúdio no topo da escada, encontrada por ele, é um convite a uma existência de desafios e realizações, de intensidade. Basta um passo. De acordo com Debord: "Quando o mundo real se transforma em simples imagens, as simples imagens tornam-se seres reais e motivações eficientes de um comportamento hipnótico"9. Durante um breve momento, Truman, ouvindo a voz de seu criador, permanece imóvel, de frente para a porta: "Você não pode partir, Truman. Seu lugar é aqui”. Parece hipnotizado pela manifestação emocionada, que revela sua existência e que lhe oferece a proteção de um mundo controlado, editado. Truman volta-se para a câmera e repete seu bordão de todas as manhãs, ao sair para o trabalho, agora para todos os telespectadores e para um incrédulo Christof: "Caso não os veja novamente, tenham uma

8. CERTEAU, op. cit. p. 288.

9. DEBORD, Guy. A sociedade do espetáculo. Rio de Janeiro: Contraponto, 1997. p. 18. 
boa-tarde e uma boa-noite". E dessa forma sai de cena, passando pela porta, indo ao encontro da mulher que ama e dos sentimentos dos telespectadores, que passam a torcer por ele e vibram por sua decisão de escapar. A vida é o espetáculo; a vida se revela maior que o espetáculo. Ao final, dois seguranças, que acompanham a atração televisiva, dialogam, após a decisão da emissora de encerrar a transmissão: "O que mais está passando?". "Vamos ver".

Resumo: Este artigo tem por objeto o filme O Show de Truman (1998), dirigido por Peter Weir e estrelado por Jim Carrey. O texto analisa a representação cinematográfica para discutir questões relativas à comunicação, à mídia e ao consumo. Com base em autores como Mikhail Bakhtin, Guy Debord, Michel de Certeau e Wolfgang Fritz Haug, o autor desenvolve uma reflexão sobre a relação entre o homem e a mídia, a linguagem como mediação, a sociedade do espetáculo e o cotidiano.

Palavras-chave: comunicação, linguagem, mídia, consumo, cinema.
Abstract: This article's object is constituted by the film The Truman Show (1998), directed by Peter Weir and starring Jim Carrey. This text analyzes the cinematographic representation to discuss relative questions to the communication, the media and the consumption. Based on authors as Mikhail Bakhtin, Guy Debord, Michel de Certeau and Wolfgang Fritz Haug, the author develops a reflection about the relation between the man and the media, the language as mediation, the society of the spectacle and the everyday life.

Keywords: communication, language, media, consumption, cinema. 